\title{
LET'S TALK LINGUISTICS
}

\author{
KRISTA KERGE
}

$\mathrm{K}$ ust jookseb rakenduslingvistika ja muu lingvistika piir? Maineka rakenduslingvistika käsiraamatusarja (HAL, 9 köidet) koostajad ütlevad, et tänapäevane edukusnõudele allutatud teadus (science under the pressure to succeed) ongi suuresti rakenduslik, sest rakendusväljund on üha sagedamini teaduse hindamise ja rahastamise põhikriteeriumeid. Nad küsivad, kas lingvistika üldse enam rakenduse-täiendit vajabki: keeleteaduse keskmesse on tõusnud või isegi tema peavooluks saanud tegeliku elu teoreetilised ja empiirilised probleemid, mille puhul keel on põhiteema. Nii peetakse õigemaks öelda, et lingvistika on teooria rakendusala, teoreetiliselt rakenduslik (theoretically applied) valdkond ühiskonna mitut laadi probleemide lahendamiseks (Knapp, Antos 2008: vii-ix). ${ }^{1}$ Kogu viidatud käsiraamat näitab sedasama mitme ala eriteadlaste silma läbi.

Kuidas paistavad keeleasjad aga eesti inimesele, kes defineerib end rakenduslingvistina? Mis tundub kirjandusest oluline ja mida see kogemuse toel ütleb?

\section{Rakenduslingvistika kui lingvisti vaatepunkt}

Lingvistikat kui te o oria rakendusala võib tõlgendada lingvistika väärtustusena kõige selle kaudu, mis üldistatuna keelepraktikast annab keelepraktikale ühtlasi professionaalseid põhjendusi. ${ }^{2}$ Näiteks on ka Christopher Brumfit (1997: 87) mõtestanud rakenduslingvistikat parimate selgituste pakkumisena keelekasutuse interdistsiplinaarsel alal. Samal ajal tasub meenutada kognitiivse lingvistika põhiteesi: „Keel on inimesel tähenduste väljendamiseks, tähendused aga ei moodusta mingit omaette, teadmistest, kogemustest jne sõltumatut süsteemi" (Õim 2008: 620). Kognitivistikale sekundeerib funktsionaalne lingvistika, mis postuleerib, et teema- ja keelevalikud on tingitud kultuurikontekstist, keelekasutuse olukorrast, osalejarollidest ja asja oludest. ${ }^{3}$ Nii nähakse tekste inimtoimingute ühe osana (vt nt Halliday, Webster 2009).

Seega ei ole keel lingvistika praeguste peavoolude jaoks autonoomne struktuur. Keel toimib

${ }^{1}$ Knappi ja Antose sissejuhatus on paigutatud kõigi HAL-i köidete algusse, millest igal on omad toimetajad: Communicative Competence of the Individual, Interpersonal Communication, Communication in the Professions, Communication in the Public Sphere, Foreign Language Communication, Multilingual Communication, Intercultural Communication, Technical Communication, Language and Communication: Diversity and Change.

2 Vt ka: Margit Langemets, Lingvistika ongi rakenduslingvistika. - Sirp 21. IV 2006.

${ }^{3} \mathrm{Me}$ ei räägi infotelefonil helistades oma poliitilistest vaadetest ega vaigista sumisevat konverentsisaali sõnadega „Jääge nüüd vait”. Kultuuriomased valikud kinnistavad kontekstiti ka keelendite funktsionaalseid ja vormilisi kooslusi (kõneakti- ja lausetüüpe, freime, kollokatsioone, rektsioone, stiili, kujundeid jne). 
a) atribuudina inimese tunnetuses (mõtlemises, tekstitajus), $\mathrm{suhtluses}$ (sõnumivahetuses, interaktsioonis ühiskonna ja selle liikmetega) ja identiteedi konstrueerimises (lõimumises rühma ja selle liikmetega ühise mõtteruumi, ideoloogia ja keelevalikute kaudu), nagu seda võimaldavad inimese tunnetusviis, loomus ja kogemus, sh hariduse laad ja tase,

b) tekstide kaudu, mis olukohaselt võtavad žanri kuju, toetavad mitmesuguseid toiminguid, eesmärke ja tunnetusviise ning kannavad, vahendavad ja raamistavad sõnumit just nendega kooskõlas.

Niisugusest vaatevinklist on keele- ja tekstinormid liik ühiskonna- ja kultuurinorme. Need normid omandatakse keskkonna toel ja inimpsüühika üldisel alusel; nad põimuvad isikuomadustega, teadmiste ja kogemusega (üldise ja keelekogemusega), mis kasvavad ja muutuvad (vt Pajupuu 2001; Langacker 2000; Õim 2008). Isikupära avaldub nende normide suhtes.

Keeleasjatundjal on omad, teaduslikult argumenteeritud vaated keel(t)e omandamisele ja õppimisele, keeleoskuse olemusele ja selle mõõtmise võimalustele; keele(kuju) ja tekstide rollile kultuuris ja kitsamas kogukonnas, inimese või rühma tegevuses või toimingutes; suhtluskanalite ja -vormide mõjukusele keelekasutuses; keele nii- või teistsugusele, selgemale ja vähem selgele, mõjusale või vähem mõjusale kasutamisele kindlas tekstis; teksti komponeerimisele ja tõlgendamisele siin ja praegu, allika ja sõnumi usaldusväärsuse, mõistmise ja vääritimõistmise põhjustele; objekti nimetuse või teksti (õpiku, kunsti- ja reklaamteksti vm) kommunikatiivsusele ehk õnnestumise võimalustele kindlat sihtrühma silmas pidades jne. Asjatundja on võimeline hindama kõike sedasama muutliku aegruumi selles või teises punktis, jagama selgitusi oma keelehariduse toel. Kõik, mida ta keelest teab, saab argumendi funktsiooni tema kindlal tegevusalal.

Nagu jurist tegeleb õigusteooria, õigussuhete analüüsi ja võrdluse, õiguspõhise kommunikatsiooni, õigusnõuande ja õigusasjadega, nii tegeleb keeleinimene keeleteooria, keelesuhete analüüsi ja võrdluse, verbaalse kommunikatsiooni, keelenõuande ja keeleasjadega. Olgu asjatundja ühiskonna keelepraktikaga seotud kui keeleõpetaja, tõlkija, leksikograaf, keeletehnoloog, toimetaja, meediaanalüütik, suhtekorraldaja, terminoloog või muus ametis, ${ }^{4}$ tema mure on toetada ikka omal alal ja omal viisil verbaalset kommunikatsiooni, parandada oma teadmiste toel selle onnnestumise eeldusi. Rakenduslingvistika üldistab nende alade praktikat keeleteaduse kaasaegsetel meetoditel ja annab praktikale tagasisidet nii teooria kui ka tulemuste toel.

Kuna inimkeele kasutusala on avar, siis nõuab keele- ja tekstitöö, s.o nii sobivate ja vajalike tekstide leidmise, loomise, vahendamise kui ka vastuvõtu toetamine paratamatult interdistsiplinaarseid arusaamasid. [Väga hästi on arusaamade ristumisi ja põimumisi oma rakenduslingvistika õpingute käigus kirjeldanud Gertraud Benke (2003).]

Ühest küljest vajatakse teadmisi keelest, semiootikast, ühiskonnast, kultuurist, kommunikatsioonist (ka kultuuriülesest kommunikatsioonist), eetikast, esteetikast ja inimesest (tunnetusest, teadmistest, emotsioonidest, mälust, tahtest, motiividest, õppimisest, isikuomadustest, ealistest iseärasustest, enese- ja maailmapildist vm). Teisest küljest tuleb suuta haakuda

${ }^{4}$ Keelel on väga suur tähtsus arsti, psühholoogi, õpetaja, juristi jt töös, kes töötavad inimestega. 
nende erialadega, kus vajatakse meie nõu, meie tõlget, meie hinnangut, meie oskust õppija eesmärkidel õpetada keelt või keelevormi, osutada nii sisu- kui emotiivanalüüsi toel midagi veebikäitlejale olulist jne. Infotehnoloogile ei saa anda soovitusi, kui arvuti loogikat ei tunne; õpetajale ei saa rääkida keelest, kui samal ajal ei võeta arvesse tema aine eripära, õpilaste iga ja individuaalseid omadusi või õppimise olemust; juristidele ei saa rääkida keelevalikutest ja teksti sobivast adresseerimisest, kui ei suudeta tabada normitehnika ja õigustõlgenduse loogikat, trafaretsuse printsiipi, alaomaseid viiteviise vm talle olulist; pangandusasjatundjale ega ametnikule ei saa õpetada kirjavahetust, kui ei analüüsita neid kirjavahetusi ega peeta silmas, kellega ja miks ta kirjavahetuses on. Ühelgi alal ei saa anda oskussõnavara kujundamise soovitusi, kui ei vallata mõisteid, mida tähistada ja suhestada püütakse, või ei aduta, millistel neist on ühiskeelde liikumise potents, millistel mitte.

Kenasti ütleb Haldur Õim (2008: 618), et „kuidagi peavad näiteks kognitiivse, funktsionaalse ja formaalse keeleteaduse uurimistulemused (mitte teoreetilised seisukohad) kokku saama, muidu ei ole enam tegemist keeleteadusega". Selle kõrval peavad rakenduslingvistikas kokku saama lingvistika ja hallatava keelekasutusvaldkonna teadmised ja kogemus, millel teoreetiline ühisosa enamasti puudub - või vähemalt puudub tihti lingvisti partneri jaoks, kelle koolihariduses on keelekasutus väga lihtsustatult kas õige või vale.

Tähendusloome ja sõnumivahetus ei piirdu muidugi vaid (loomuliku) keelega. Theo van Leeuwen (2005) räägib ühiskonna ulatuslikest semiootilistest ressurssidest, mis kätkevad ilmseid kommunikatsioonimooduseid, nagu keel, žestid, visuaal või muusika, kuid ka vähem ilmseid, nagu toit, riietus jm argiobjektid, mis kannavad väärtusi ja tähendust kindlas kultuuris. Semiootika objekt on nüüdisaja tekstid kui tähendusvahetuse komplekssed multimodaalsed üksused, mis hõlmavad kujundust, visuaale, heli ja rütmi. Selgituse või argumendi annab keelekasutuse analüüsis üha enam too tähtsustuv sõnatu tugi: kuidas kasutame häält, suhtlusruumi, näoilmeid, silmsidet, žeste, riietust, liikumist, illustratsioone; kuidas kujundame väljaandeid trükisena või lingime neid võrgukeskkonnas.

Seegi nimekiri ei ole ammendav, sest ei hõlma sotsiaalsete suhete tähendusi, näiteks õigusakti jõudu olukorras, kus regulatsioon eetilistel alustel isepäi toimib; tööandja ulatuslikku vastutust võrreldes töötajaga; meedia vastutust olukorras, kus avaldatud sõnumite valik, vorm ja tõlgendusvõimalused pole aluseks mitte ainult ühiskonna väärtussüsteemile, vaid isegi maailmamajandust mõjutavatele aktsianoteeringutele börsil, kui tuua vaid mõni näide.

\section{Globaliseerumine ja rühmitumine meie ümber ja meie seas}

Mõtestada keele toimimist siin ja praegu on üsna raske ülesanne, kuigi samal ajal on ühiskonna nõudlus keeleasjatundmuse järele väga suur. See on ka loomulik ajastul, mida võib nimetada suisa Sapiri-Whorfi hüpoteesi apoteoosiks. Globaliseerumine kahandab kindlas kultuuriruumis ühist kultuuri- ja tunnetuskonteksti Edward Halli tähenduses ning kasvatab sõnalise suhtluse osatähtsust (vt nt Pajupuu 2001). Trükimeedia on avaliku sfääri infoallikast (osati) muutunud privaatsfääri teemasid müüvaks ja nappi asjalikkust agressiivsusega varjutavaks sõnavahuks ning reklaam loob lastes mõtle vate 
molekulidega maailmapilti. Meie elu reguleeritakse õiguslikult ehk sõnaliselt sellisel määral, et JOKK-efekt on tugevam kui hea tava, mis justkui oleks õigusloome põhialus ning õigustõlgenduse olulisi tahke. ${ }^{5}$ Süüdlase rollis on tugevasti ka neoliberalismi odava riigi ideoloogiaga paratamatult kaasnev (ja ülimalt kulukaks osutuv) kontrolliv bürokraatia, mis pidurdamatult kasvab (vt nt MacEwan 1999). Sel kõigel on suur mõju keelele (vt nt Kerge 2006, 2010; Aava 2011).

Keeleasjade ajamise raskusel on kaks olulist ja tugevasti seotud plaani: mis toimub Eesti ühiskonnas ja mis toimub eesti lingvistikas. Need on ühe ja sama probleemi kaks avaldumistasandit.

Globaliseerumine tähendab ühelt poolt standardiseerumist, kultuuride ühisosa ja ühise mõistevälja kasvamist, ideoloogiate sarnastumist, poliitilise korrektsuse ja positiivse väljendusviisi nõude mõju keelele ja selle kasutamisele jne. ${ }^{6}$ Teiselt poolt tähendab üleilmastumine ühe kultuuri sees normipaljusust ehk omi standardeid kultuuri- ja keelepiire ületavates identiteedirühmades, kelle lingua franca'ks on üha selgemini kujunenud inglise keel. Rühmitumine on seega üleilmastumise lahutamatu tahk. Eesti räppmuusikud ja nende fännid kuuluvad kogukonda, mille piirid ületavad kultuuri- ja keelepiire ja mille kese on mujal. Keeleülene identiteet või pragmaatiline vajadus mitmes keeles tegutseda (nt ingliskeelne töö ja jätkuv õppimine) on pigem reegel kui erand. Eesti keele kese hajub, ühiskeele piirid ahenevad ning sõltuvad suuresti kohalikust formaalsest üldharidusest ja laia kasutajaskonnaga meediast. Viimane tähendab ka võrgukeskkonda kõige sellega, mis seal enamusele huvi pakub.

Ka lingvisti kui eesti keele teadlast ei ole enam olemas: on järjest lisanduvate alade või meetodite asjatundjad, nende erialaidentiteedi kese, peamine ideoloogiaallikas ja mõistev „samakeelne” lugejaskond on väljaspool Eestit ning teadusrahastuse ja -hinnangu - siis ka ülikoolis õpetamise - eeldus ongi, et see nii oleks. Arvestatavad teadmised on sedavõrd spetsiifilised, et rakenduslingvistil kui eesti keele vitaalsuse professionaalsel toetajal on raske püsida professionaalne. Me räägime eri keeltes.

Juri Lotman (1992) on samas väga veenvalt näidanud, et mõtte areng eeldab tähenduste vahetust semiosfääride ehk tähendusi jagavate kogukondade/ tekstide kokkupuutealal. See on sügava spetsiifilisuse vastandolukord. Probleem haakub ka keeleteadusliku arusaamaga tekstide vältimatust ideoloogilisusest (vt van Dijk 2005): iga kitsama eriala lingvist mõistab keele toimimist ja omaenese rolli selle juures erinevalt. Kui oleks võimalik, et ühe keeleteadusliku paradigma, keelekäsituse ideoloogia ja uurimisobjektide ringi külge aheldatud keeleteadlased püüaksid oma arusaamisi teiste omadega

\footnotetext{
5 „Eesti on oma üleseadustamise ja korruptsiooni ning inimvaenuliku poliitikaga paras pähkel," ütleb end endise ettevõtjana tituleeriv inimene Delfis. Ka Riigikogu stenogrammidest leiab üleseadustamisele viitavaid märkusi juba üsna ammu; vt nt http://www.riigikogu.ee/?op=steno\&stcommand=stenogramm\&day=22\&date=953118000\&pkpkaupa=1\&paevakord=2000006472 (25. V 2012). Samas on hoiakud seaduste rohkuse suhtes nii- ja naasugused; näiteks leiab fraasi „liiga palju seadusi” guugeldades 827000 päringuvastust (tõsi, osa leitud tekste kombineerib fraasi osi), kuid palju vähem pole ka hüüatusi, et seda-teist valdkonda tuleks seadusega reguleerida või teha seda täpsemini (416 000 tulemust otsinguga „vajadus seaduse järele”).

6 Vt nt sõnakasutuse suuniseid võrgukeskkonnas: Positive Adoption Language. OURS Magazine, May/June 1992. http://www.adoptivefamilies.com/pdf/PositiveLanguage. pdf (25. V 2012).
} 
suhestada, ${ }^{7}$ siis oleks lootust, et keele toimimise jaoks oluline saaks pideva moodsa mõtestuse ühiskonnas laiemalt. Eestikeelse teaduse olulisi funktsioone on ju hoida eestikeelne üldharidus, s.t kooli- ja meediaharidus, moodsana (vt Kerge 1994, 1998). Teisalt peab keskkond sellist dialoogi pidevalt toetama, keeleajakirjad ei tohi muutuda lugejakontekstiga suhestamata granditulemuste avaldamiskeskkonnaks, kuid sinna asi kipub. Ise tunnen vajadust, et ka iga ERÜ aastaraamat algaks mõne aeglasema, esseistliku ja üldistava looga aasta teemal.

Sealpool piiri ei ole asi teisiti. Keskkond The Linguist List ${ }^{8}$ pakub 773 indekseeritavat keeleteaduslikku ajakirja, jagades nad 26 avarama allvaldkonna vahel, raamatuid osutatakse ainuüksi seal 9662, lisaks 2183 väitekirja kokkuvõtted. Kui palju on selles kõigile olulist, ei oska oletadagi. Väga sageli on tunne, et lihtsam on end selgeks teha keelevõhikule kui kolleegile. Probleem pole tingimata midagi uut, kuid on laienenud kõikjale ja see muudab maailma.

Majandusteadlaste väitel on konsensuse nõue teaduskirjanduses vaidluste objektiks juba Kanti aegadest alates (Homann, Suchanek 2009: 17). ${ }^{9}$ Konsensuse saavutamise raskust on praegu tunda igal teadusalal ja Eestis iseäranis. Ka ühe ja sellesama juuspeene ala asjatundjatel on raske leida ühist platvormi, sest eeltoodud arvude taustal on selge, et neist igaühe lugemus on erinev ja diskursuseterviku aspektist piiratud. Sel ajal kui (kui!) lingvistikavoolud maailmas suhestuvad ja diskuteerivad, ${ }^{10}$ jääb eestikeelne koolkondlik keeleteadus ajast lihtsalt maha või hoopis ruttab ette, sest meid on kole vähe.

Lingvistil on niisiis õige taanduda oma kõrgteadusse ja kirjeldada muuhulgas seda, kus meie keel püsida võiks ja kust ta kaob. Ometi töötab see tegelik ja individuaalselt loogiline mõtteviis, mida riik oma teaduspoliitikaga toetab, kõige otsesemalt riigi enese vastu. Kuni on olemas riik, mille eesmärk on säilitada ja kultiveerida eesti kultuuri - hallata meie elukeskkonda, säilitada ja arendada eestikeelset avalikkust ja (sisult, mitte vormilt!) konkurentsivõimelist haridust, võimaldada eestikeelset igapäevaelu, kunsti ja tööd -, seni on ka seda kandva keele asjatundjatel mõtet oma töö ühisosa otsida. Me oleme natuke riiki.

Eesti postuleerib avalikult, et erinevus rikastab, kuid unustab sellesama deviisi kohe, kui juttu on kaasajas püsiva eesti keele olemasolust Euroopa Liidu riigi keelena, ${ }^{11}$ mitte kodukeelsest eestlasest „igas sadamas”. Kui mõelda keeletöö tähtsusele, siis ei aita siin üksiti riiklikud programmid ega projektid, vaid teadus- ja hariduspoliitika üldine sirgeselgsus. Teadmispõhine Eesti on lihtsalt loosung. On aeg ametlikult tunnistada, et teadus on oma tulemustest kasvavate hüpoteeside ja rakenduste püramiid, mille tipp ei püsi ajalehelugudel, vaid hoolikalt ehitatud tervikul. Teadusteadmise kinnistumist ühiskonnas ei saa mõõta meediakajastustega, ${ }^{12}$ vaid levikuga kõigi ja kõige-

${ }^{7}$ Näiteks nagu Õim, Tragel 2007; Haldur Õimul on lingvistikaharude suhestamisel üldse eriline roll.

8 The Linguist List. International Linguistics Community Online: http://linguistlist.org/.

9 Tsiteeritud e-väljaanne on aadressil http://kiru.planet.ee/raamat/Raamat\%20II.doc (30. V 2012).

10 Viitan oma kui-ga nn SIG-efektile (special interest groups kitsamagi eriala sees).

11 Vt ka arutlusi loos „Eesti kirjakeele mõtteruum” (ESA 49, lk 7-22), mida saab veebis pealkirja järgi leida.

12 Viitan siin aruannetele, kus teadusasutustelt ja nende üksustelt küsitakse tippväljaannete artiklite arvu ja samal ajal just avalikus meedias (Õpetajate Lehes, Sirbis, 
ni, kus nad kõnekad võiks olla. Nii tähendab kogukonna vaimne jätkusuutlikkus iga 1.1 ja 3.1 kategooria artikli kohta kolme teisiti adresseeritud eestikeelset (1.3, 3.2 jne) artiklit või mitmesuguseid eestikeelseid raamatuid ja nende peatükke, nagu eriala võtmeteoste tõlked, eri sihtrühmade ja suunitlusega aine- (k.a keele-) kirjeldused, aimeraamatud, kõrgkooli- ja kooliõpikud, millele kogukonna teadmuspüramiidi tipp saab toetuda. Kui meid on kokku vähe, siis peaks ka iga doktori eksperdiroll oma riigis ilmnema tema kirjutiste ja suuliste publikatsioonide toeka püramiidina, k.a mitmesugused täiskasvanukoolitused ja esinemised avalikus meedias, mitte (ainult) Thomson Reutersi mõjukusindeksina.

Tegelikult on üleilmastumise problemaatika veel laiem. Virtuaalmaailm ja mobiilsus muudavad reaalsust ja teisendavad olulisi mõisteid. Laste kasvukeskkond on mitmekeelne, mis tähendab, et emakeele mõiste ei ole seesama mis 100 või 30 aasta eest. Ingliskeelsuse vabatahtlik ja kasvav ulatus eesti õpilaste seas tundub lausa drastiline (vt Tammemägi, Ehala 2012). Keelekujud ei ole needsamad mis paari aastakümne eest, sest suuline suhtlus on suuresti asendunud tempoka ja ligi pideva kirjaliku virtuaalsuhtlusega. Keelenormid ei ole pea kuskil püsivad, sest norm on omane identiteedirühmale (ja ma ei mõtle ettekirjutusi, vaid seda, mis vormis on kombeks sõnumeid/ tähendusi vahetada). Eesti keele kese, ühiskeel ja sellele toetuv kirjakeel hajub - aga emakeel omandatakse ju keskkonnast. Infopaljusus kui ajastu teine mina võimendab seda protsessi paratamatult ja väga kiiresti, määravaks on muutumas keelehoiakud.

Globaliseerumisel on aga veel üks tahk, kus inimese ja ühiskonna vaatenurk võivad erineda. Kui üleilmastumine eeldab mitmekeelsust ja toetub mitmekeelsusele, siis võime kognitiivset mitmekeelsust (plurilingvalismi)13 Euroopa mobiilsuse huvides ja kakskeelsete perekondade laste näitel kiita, kuid ükskeelsena kasvanud indiviidi aspektist on seegi probleem. Näiteks viidatakse ühe kakskeelsust taotleva Singapuri riigiprogrammi mõõtmistulemuste toel, et umbes 40 \% õpilastest ei ole kakskeelsuseks võimelised, vaid saavutavad teises keeles vaid miinimumtaseme (Bokhorst Weng 1999: 238). Ôpilase aspektist on kakskeelsus seega ühiskonna probleemne ideaal, räägitagu siis eesti-vene kakskeelsusest, mida taotleb meie riik, või eesti-inglise kakskeelsusest, mis on vabatahtlik (vt eespool). Eesti keelekogukonnad on mitmesuunalise surve all, mis vajab omakorda nii ühiskondlikku mõtestamist kui ka rakenduslingvistilisi järeldusi (vt ka Frath 2009). Kui võõras keeles sotsialiseerumise eesmärk on ebarealistlik kas või osaliselt, siis on ühiskonnal just elanike selle osaga võrdeline tõsine sotsiaalne probleem, mida keeleõpetuse viisidega ja hoiakute muutmisega ei lahenda. Kui aga mõtleme eesti- keelsuse absoluutarvudes napile potentsile, siis on globaalsete suundumuste poliitiliselt pime võimendamine hariduses otseselt ohtlik ja ühtlasi vastuolus keelte nägemisega maailmakultuuri rikkusena. Rääkimata sellest, et kurikuulsas multikultis (ja seega globaliseerumises ja mobiilsuses) võibki olla paikamatu auk, mis eirab inimese individuaalseid keelevõimeid või mingis keeles sotsialiseerumiseks vajatavaid etappe - või ajab segi keeleoskuse, verbaalse

raadios, TV-s) publitseerimise kordi, pööramata vähimat tähelepanu sellele, mis sinna vahepeale mahub.

$13 \mathrm{Vt}$ Euroopa keeleõppe raamdokument. Õppimine, õpetamine ja hindamine; osa 8, lk 175. http://www.hm.ee/index.php?popup=download\&id=5700 (20. V 2012) - allikaid leiab hõlpsasti ka pealkirja järgi. 
ja üldise võimekuse. ${ }^{14}$ Millest ei saa või ei tohi ausalt rääkida sõnadega, sellest räägitakse põlevate autode ja rusikate keeles.

Esialgu on kognitiivseid probleeme kinnitavaid teadustulemusi üldistuseks liiga vähe, kuid praktikas igal pool kinnitust leidnud kätega rääkimise senised selgitused ilmselgelt ei tööta.

\section{Keelekirjeldus, keelesüsteem ja kommunikatsioon}

Keelekasutus ja kommunikatsioon on toeka ühisosaga nähtused.

Gunther Kress (2000: 142) kirjutab, et emakeele aine tuleks nimetada kommunikatsiooniks, liita sinna visuaali lugemine, hüpertekstikujundus jms multimodaalse suhtluse ja infoajastu jaoks oluline. Moodsat kirjutamist nähaksegi pigem sõnumikujundusena (shaping kaasab kõik sõnumivahetuse moodused ja vahendid) kui keelekasutusena traditsioonilises mõttes (vt nt Kress, Leeuwen 2004; Kress 2007).

Mõneti sekundeerib Kressile Karol Janicki (2011), kes kirjutab kommunikatsioonimüütidest kui tavakasutajale omasest ehk asjatundmatust vaatest tähendusele ja suhtlusele. Üldlevinud väärarusaamade peasüüdlased on kriitiku arvates just keeleasjatundjad (nii keelefilosoofid, leksikograafid kui ka näiteks kognitivistid), kes on jätnud mulje, et sõnumivahetuse ebaõnnestumise korral aitab vigade parandusest. Alternatiiviks on Janickil veendumus, et tähenduse omistavad sõnadele inimesed. Inimeste hulka ei näi ta arvavat ei keeleasjatundjaid ega keele tavakasutajaid; normi, sh rühmaja kontekstinormi on ta oma arutlustes välistanud (vrd nt Kecskes 2008 või Halliday elutöö) ega viita ka keelepädevust mitmekülgselt mõtestavale kirjandusele. ${ }^{15}$ Teisal irvitab sama autor oma akadeemiliste kolleegide väljendusviisi üle, leidmata ruumi terminoloogia olemuslikule otstarbekusele või arutlustele oskuskeele adressaadi teemal (Janicki 2010). ${ }^{16}$

Olgu nende Janicki naerutatud keele- ja keeleoskuskirjeldustega, kuidas on - küllap ei ole lootust näiteks konstruktsiooni-, mõiste- vm skeemidena esitada kõiki rohkete morfovormide rohketest funktsioonidest tingitud konstruktsioone, metafoorseid ja metonüümilisi tarindeid, arvestades ühtaegu eesti keele eripära, inimese psüühikat (mind), üldistus- ja analoogiavõimet ning taju tööprintsiipe. Keele toimimisele on aga viimase veerand- või poolsajandi praeguseks peavoolu jõudnud teooriad andnud suurepäraseid seletusi (vt vahendusi: Õim 1996, 2001a, 2001b, 2008; Kasik 2002; Rannut, M., Rannut, Ü., Verschik 2003; Ôim, Tragel 2007; Sahkai 2011; Aava 2011; Lakoff, Johnson $2011 \mathrm{vm})$.

Vahest ei ole Eestis kuigi laialt tajutud, et süsteemikesksuse ületamine keeleteaduses on tegelikult andnud meile teistsuguse keelesüsteemi, kus norm - igasuguse verbaalse kommunikatsiooni otstarbekas alus - ei ole kõnelejaskonna teadvuses pelgalt leksika ja grammatika ühisosa, vaid sisaldab ka sotsiaalsete kontekstide selget süsteemi ning kontekstinihete inimmõtlemi-

14 Viitan inglise-, saksa- ja prantsuskeelsetele maadele, kus laps tõrjutakse siiani 10-11 aasta vanuses n-ö kutsekooli suunale, aga ka mitmete rahvusvaheliste funktsionaalse lugemisoskuse uurimuste tulemustele, kus muu emakeel ja meessugu on sageli seotud keskmisest halvema tulemusega.

$15 \mathrm{Vt}$ üldplaani ja rohkeid viiteid nt Kerge 2008 või Knappi ja Antose järgi viidatud HAL, kd 1.

16 Jätan siinkohal teadlikult kõrvale selle, mis Janicki (2010) raamatus on asjalikku ja head. 
sega argumenteeritud süsteemi, mis mõlemad töötavad sõnumivahetuse õnnestumise huvides.

Ebamääraselt taustapositsioonilt on otse igapäevaste keelevahendite teksti loome ja tõlgenduse vahendite - kirjeldusse nihkunud mitu vältimatut ja toekat atribuuti, mida keeletöös üheaegsete argumentidena kasutada:

1) mitte lihtsalt leksika ja grammatika, vaid sõ n a de ja gram mati ka funktsiona lne koostoime. Selle kirjeldus (k.a nii laiem kognitiivne kui ka konstruktsioonigrammatika) aitab mõtestada ja selgitada keelendite tähendusi ja tähendusnihkeid tasand-tasandilt alates sõnaloomest ja morfosüntaksist kuni aine- või suhtlusvaldkonna tekstikoosluseni (vt Halliday, Webster 2009; Langacker 2000; Sahkai 2011 jm);

2) sotsiaalsed ja isiklikud kontekstid, mis avalduvad olukohase žanri kaudu (vt nt Kecskes 2008; Hasan 2009). Need aitavad lahus hoida ja lõimida keelendite tähendusi ja konnotatsioone ning näha neid kas variandinormi osana või eripära ilminguna - viimane võib omakorda olla juhuslik või tüüpiline, mida saab tunnetada vaid aega, inimest ja taustarühma (identiteete ja rolle) tundes;

3) inimtunnetuse mentaalsed mudelid koos mitmesuguste selginevate arusaamadega - näiteks sellest, kuidas figuur eraldub astmelise konteksti foonil situatsioonist ja žanrist fraasini; milliste sammude kaupa üldistus liigub konkreetsest abstraktsema suunas, hakates sealt teatud astmel ja taustal äkki tagasi liikuma, või sellest, kus kujundi analoogia on ilmne mingi kogemuse tõttu, mida on võimalik kirjeldada (vt Tragel 2003; Õim 2008; Langemets 2010; Lakoff, Johnson 2011 vm).

Need mentaalsed mudelid määravad normi tekke/muutuse kontekstitaju toel; nad lubavad seletada nii keelelise normi kui ka loovuse olemust ja seda, miks kultuuriruumi ühendav norm moodsal ajal kahaneb. Selginenud arusaamad keele sotsiokognitiivsest süsteemist ja tema suundumustest põhjendavad, miks me suudame tekstide abil suhelda, tekste luua, mõista ja vahendada (sh juba minimaalse sotsialiseerumist lubava keeleoskuse juures). Kui igasuguse inimkommunikatsiooni püüdeks ongi mõistmine, siis on mitmeti- ja vääritimõistmine sisse kirjutatud kommunikatsiooni olemusse.

Kuigi tõlgenduses mängib pidevalt kaasa kahe osaleja kattumatu kogemus ja erinev mentaalne kontekst, on sarnases kultuuri- ja keelekeskkonnas kasvanud inimestel paratamatult ka ligilähedaselt sarnane kogemus, sealhulgas keelekogemus, mõistete tähistamise ja konnoteerimise ühisosa, hariduse ja olustiku ühisosa ning siduv žanrikogemus. Žanr - mitte üldistus, vaid olukohane suuline või kirjalik žanr, milles kindla valdkonna tekst on vormista$\operatorname{tud}^{17}$ - defineerib suhtluspartnerite rollid ning loob vastuvõtuootused, andes tõlgendusele primaarse konteksti otse vahetu toimingu raames. Tõlgendusvõimaluste analüüsi toetavad tekstuaalsuse koondatud printsiibid ja tekstilingvistika alused, kuid ka mitmesugused mõõdetavad erinevused žanrite ja tekstide vahel, mis on tingitud nii keele kasutusest kui ka kasutajast (vt de Beaugrande, Dressler [1981] 2002; Tannen 1991; Biber 1995; Langacker 2000; Kecskes 2008 jpt).

17 Situatiivne ehk olukohane žanr on tegelik kultuuriilming, millena tekst esineb (nt ametlik e-kiri ja isiklik paberkiri; tavakooli VI klassi ajalooõpiku õpitekst või õpiraskustega täiskasvanule suunatud õpitekst samal teemal); üldžanr on tekstide sarnasel funktsioonil ja kompositsioonil põhinev üldistus (nt kiri või didaktiline tekst); vt viiteid ja arutlusi: Puksand, Kerge 2012. 
Kommunikatsiooniteadust näib samas keeleteadusega ühendavat liiga vähe. Leiame semiootilise ja filosoofilise kallakuga teoseid, milles ühisosa on suur (nt Cobley 1996 kommunikatsiooniteooria lugemik sisaldab Saussure'i, Peirce'i, Barthes'i, Eco, Lacani, Halliday, Kressi, Leeuweni, Jakobsoni, Palmeri jm tuttavaid artikleid). Peamine ühenduslüli näib rohketes erialakäsiraamatutes siiski olevat Paul Grice (vt nt Greene, Burleson 2003: 13-14; Littlejohn, Foss 2009: 292), keda võidakse ka kritiseerida (Pavitt 2001: 182; Trenholm 1991: 101-103). Samas liigitavad ja seostavad kommunikatsiooniteadlased keeleinimese kui võhiku jaoks igati usaldusväärsel viisil suhtlust kultuuris ja kultuuride vahel; isikulist, grupi- ja massikommunikatsiooni, töist ja vaba suhtlust, sümmeetrilist ja asümmeetrilist kommunikatsiooni jne, kuid paraku ei ole seal kohta ei žanritel ega terviktekstidel.18 Otsene kokkupuude keeleasjatundmusega on kommunikatsiooniteaduses napp. Näiteks eksisteerib keelepõhise suhtlusvea termin (language-based failure; vt Berger 1998: 97), kuid keeleinimene liigitab suhtlusveaks palju enam keelekasutusprobleeme: mitmeti- ja vääritimõistmise eeldused on teksti sisse kirjutatud kompositsiooni, omapoolse või vahendatud info asjakohatu sisu, valiku või mahu kaudu jne (vead, mida saab liigitada ka Grice'i kommunikatsiooniprintsiibi ja suhtlusmaksiimide toel; vt nt ametnike kohta Kerge 2006; Kasik 2007). Teksti lingvistiline analüüs on sotsiaalteadlastele laiemalt tuttav pigem metoodikast (kontentanalüüsi võttena ja diskursuseanalüüsi eeldusena; vt nt Wodak, Krzyżanowski 2008).

Keeleinimese silmis on asjaliku kommunikatsiooni põhiüksus (verbaalne) tekst ning mõneti jääb kommunikatsioon alati personaalseks. ${ }^{19}$ Keelekasutuses läheb oluline piir privaatse ja esindussuhtluse vahelt: asjalikkus ja standardsus käivad käsikäes ja välistavad sisu esilduvuse nimel isikupära nii palju kui võimalik. ${ }^{20}$ Kommunikatsiooni verbaalne tahk oma žanri- ja rollispetsiifikaga pakuks siin kahe teadusala lõimimiseks olulise aluse. Teisalt võtab inimene isegi privaatsuhtluses alati arvesse kellegi hoiakuid (Palmer 1998: ix) ja esindab suheldes alati mõnd oma identiteeti. Kommunikatsiooniteadustes ongi tugevasti arenenud rolli- ja nähtusspetsiifika uurimine (kliendisuhtlus, arsti-patsiendi või õpetaja-õpilase suhtluskoostöö, keeleline vägivald jpm), kus keele roll on ilmne. Käitumismõjutuste keeleline külg21 on eesti lingvistikas samal ajal jäänud peamiselt meediaanalüüsi ja mõtteviisimõjutuste temaatika juurde (vt nt Kasik 2002, 2007; Aava 2011, taustal van Dijk 2005).

Ala otse kutsub koostööle.

18 Igatahes ei leidu mitmes raamatukoguvõrgu kaudu sirvitud kommunikatsiooniõpikus üldse genre'i sõna.

19 Kommunikatsiooni termineid tuleb interlingvaalsel põhjal väga ettevaatlikult sobitada: personal communication tähendab isiklikku, interpersonal inimeste suhtlust eristatuna rühma- ja rühmade omast (intra- ja intergroup communication) ja social hoopis seltskondlikku lävimist. On tekkinud ka uusi termineid, nagu masspersonal communication, mis võrgukeskkonda arvestades püüab kommunikatsiooniteaduse seniseid liigitusi ületada; vt nt Patrick B. O'Sullivan, Masspersonal Communication: An Integrative Model Bridging the Mass-Interpersonal Divide. Illinois: Illinois University. Center for Teaching, Learning \& Technology. http://calpoly.academia.edu / PatrickBOSullivan / Papers / 457584 / Masspersonal _communication_Rethinking_the_mass_interpersonal_divide (25. V 2012).

20 Siinkohal viitaksin ka keele normimise vajadusele, mida olen hiljuti kirjeldanud; vt Keelekorraldus: kas ka täna? - M. Raadik, T. Leemets (toim), Sõnaga mõeldud mõte. Pühendusteos Tiiu Ereltile. (EKI toimetised, nr 14.) Tallinn: EKSA, 2012, lk 67-75.

${ }^{21}$ Kirjandust, mis seob psühholoogia ja kommunikatsiooni, leiab märksõnaga persuasion. 


\section{Ühiskond ja keeleoskus}

Eestis hinnatakse normeeritud ja valikutelt võimalikult neutraalset (n-ö igale poole sobivat) keelekuju ja see on ehk eeltoodud arutluste taustal ka mõistetav. Kaotades ühtviisi tajutava ühiskeele, kaotame osa haritud eesti keelest koos tema pika pärandiga. Nii kaob põlvkondade ja sotsiaalrühmade arusaamade ühisosa ja keele kui mõtteruumi avarus, kuid ühtlasi ka midagi olevikus olulist - me ei mõista ühiskirjakeeleta kuigi nüansirikkalt oma õigusi, terviseseiku, tööasju jpm. Lapsesõbraliku kooli ideoloogia lihtsustab tulevase ühiskonnaliikme niigi lihtsustuvat tekstimaailma, kuid täiskasvanuelus on massiliselt uue sisuga keerukaid tekste, mille alusel tuleb toimida.

Samal ajal ei luba üleilmastumine, emakeele mõiste teisenemine ja funktsioonide kitsenemine jääda kinni sõnumivahetuse vormiideaalidesse: näiteks pole asjalikemaski sõnumivahetuses erilist tähtsust sellel, kuidas sõnumi looja on sõnu käänanud, kas ta on komaga märkinud kõrvallause lõppu ja ees, toonud nimena käibiva fraasi esile läbiva suurtähega või tajunud seda üldsõnajadana. Keelehoole ja keeleõpe peaks Eestis kahandama oma esoteerilisi hoiakuid ja enam arvestama mitme keelekasutusjuhise ühisala paratamatust (vt nt Kerge 1994, 1998).

Maailmas ongi keeleõppe tähelepanu fookuses filoloogi ideaalide saavutamatus: inimese keeleoskust ei tohi hinnata võrdluses standardiseeritud ehk normatiivse keelekasutusega, milleni isegi filoloogist emakeelekõneleja ei pruugi jõuda (vt Taylor 2006). Ideaalse standardini jõudmise raskustele viitavad ka eesti noorte emakeeleoskuse hiljutised uurimused (Ehala jt 2010; Kerge, Meier 2010).

Et uurida haritud mittefiloloogide kirjalikku keelekasutust, mida eesti ühiskond laiemalt peab vastuvõetavaks ehk loomulikuks, tegime katse panna kõrgharitud eestlased eesti keele kõrgtaseme eksami vormis ${ }^{22}$ esseed kirjutama. Hindasime seda arusaamas, et loomulik keel avaldub (situatsiooni ja žanrit arvesse võttes) hästistruktureeritud tekstina, mida iseloomustab spontaansus ja ladusus, oskus kasutada keelt paindlikult ja tulemuslikult. ${ }^{23}$ Selline keel lubab vastuvõtjal keskenduda sõnumi sisule, sõnumist arusaamist ei sega keeleüksuste valik, vorm, järjestamine ega sidumine - just niisugust arusaadavat loogilist tervikut meie katses osalenute tekstid näitasidki. Mida tahes teeks haritud eestlase tekstiga keeletoimetaja või millega poleks rahul keeleõpetaja, niisugune haritud inimese tekst sobib etaloniks, mille alusel hinnata muu emakeelega inimese sama žanri tekste ja seada emakeele riigieksamigi latti. (Vt kirjeldust ja viiteid: Pajupuu jt 2010, ning esialgsete katsenäidiste analüüsi: Kerge 2008: 220-225.24)

Tegelikult on aga kirjaoskuse ja kirjakeelsuse mõistmises selged käärid ja olukord Eestis ei viita kuidagi euroopaliku võrdse kohtlemise ideaalile. Muu emakeelega noorte eesti keele oskuse mõõduks on kommunikatiivne toime-

22 Mõeldud on riiklikku tasemeeksamit, mille sooritamist katse ajal keeleseaduse järgi nõuti nt kõrgetelt riigiametnikelt, arstidelt, eesti keele õpetajatelt, ohvitseridelt, s.t ainult mõnes kõrgharidust eeldavas ametis.

$23 \mathrm{Vt}$ Euroopa keeleõppe raamdokument. Õppimine, õpetamine ja hindamine, lk 25. http://www.hm.ee/index.php?popup=download\&id=5700 (20. V 2012).

24 Praeguseks on uurimust laiendatud ka täiskasvanud keeleomandajatele ja eesti õpilastele, analüüsides kirjutusoskuse liikumist haritud keelekasutuse suunas ning selle sisendkeelena õpikutekste ja -sõnavara (Puksand, Kerge 2012). 
tulek, eesti noorte puhul selle kõrval tugevasti ka (jäik) õigekeelsus ja stiil, nagu eesti filoloogist kooliõpetaja seda hindab. Just riigieksamitest sõltuvad aga noorte inimeste edasised eluvõimalused. Kui probleemile naiivselt läheneda, siis tundub, et asja lahendab sarnane eesti keele küpsuseksam lähedaste ülesannete, õigekeelsus- ja stiilinõuetega. Tegelikult see nii ei ole.

Asjalikku emakeelekasutust ei õpita ju emakeeletunnis, vaid igas tunnis. Kogu kohustusliku koolihariduse eesmärk on kirjaoskajate inimeste kasvatamine ja pedagoogika räägibki mitme aine kirjaoskusest (näiteks ajaloo-kirjaoskus jm kui aineteadmiste baas koos oskusega ajaloo teemadel kaasa rääkida). Aineteadmiste eakohase pakkumise kõrval harjutavad õpikud üha täiskasvanulikuma keelekasutusega ja panevad ühiskirjakeelele aluse - just koolihariduse keel ja sinna jõudev osa terminivarast on ühiskeele oluline komponent. Et emakeel omandatakse kindlat tüüpi tegevuste ja olukordadega kaasas käivatest tekstidest, siis peetakse koolis oluliseks pakkuda õpiteksti kõrval igasuguseid autentse teksti liike, mis õpiteksti täiendavad ning kasvatavad žanriharjumusi seal, kus noore kokkupuude nendega automaatselt tagatud ei ole. Siiski ei ole õpikute keel järjekindlalt eakohane (vt pikemalt: Puksand, Kerge 2012).

Erilise tähtsuse saabki keel õppimise vahendina - see eeldab kogu tekstitöö metakognitsiooni: miks ma loen, mida ma valdkonnast juba tean, mida ma valin, miks see tekst, mida ma sealt leida eeldan, mida ma välja märgin, miks ma aru ei saa, kust ma seletusi leian, kuidas asja enese jaoks sõnastan, mis ma selle infoga edasi teen, kui püsivalt ma seda vajan jne. Kõike sedasama võib küsida kuulamise kohta, kuid väga sageli tuleb alustada teisest otsast: kui ma tahan kirjutada või pidada suulise ettekande kindlal teemal, siis kes ja mida on sellest juba kirjutanud? Kas ma otsin süvainfot ja loen läbi mingi raamatu või otsin ma teatud fakti, määratlust, hinnangut, mille leian artiklitest üsna kompaktselt ja tekstisse süvenematagi (olgu paberil või veebis)? Mida ma lugejatele-kuulajatele öelda tahan? Kuidas - kui pikalt, mis sõnadega - ma loetut vahendan? Kas loetuga samas järjekorras või mingil teisel alusel? Mida mul on lisada? Jne, jne.

Kogu õppimine kujutab endast tekstide vastuvõtu, vahendamise ja loomise kombinatsiooni, mille teadvustamisest sõltub õpiedu ja tulevik. Suurel määral keelega seostuva metakognitsiooni tähtsus õppimises on sedavõrd suur, et sel alal on järjest koostatud käsiraamatuid (nt Holyoak, Morrison 2005; Hacker, Dunlosky, Graesser 2009) ja neid on juurde ilmumas. ${ }^{25}$ Valdkonna arendamise eesmärk on inimese elukestev oskus õppida, mistõttu Springeril ilmub ka metakognitsioonile ja nn enesejuhitud õppimisele (self-regulated, selfdirected learning) spetsialiseerunud ajakiri Metacognition and Learning.

Kõige kirjeldatu puhul on tegelikult fookuses mitu keelt, sest info allikad on mitmes keeles. Emakeeleainetel on keele- ja tekstiteadlikkuse-tundlikkuse loojana ometi väga oluline roll - siin tuleb tõmmata piir kunsti, ajaviite ja asjalikkuse, kunsti- ja tarbeteksti vahele ning luua kriitiline suhe igat liiki tekstiga. Mida me emakeeles ei taju ega oska sobivas vormis väljendada, seda ei saa ka võõrkeeles omandada.

Mõneti on meil emakeeleõpetuse asjad hästi. Eesti on väheseid kohti maailmas, kus vähemalt põhikooli teisest astmest alates - ja suuresti tänu

$25 \mathrm{Nt} \mathrm{R.} \mathrm{Aze} \mathrm{ved} \mathrm{o,} \mathrm{V.} \mathrm{A} \mathrm{l} \mathrm{e} \mathrm{ve} \mathrm{n} \mathrm{(toim),} \mathrm{International} \mathrm{Handbook} \mathrm{of} \mathrm{Metacognition} \mathrm{and}$ Learning Technologies. Berlin: Springer. 
Sirje Nootre õpikomplektile (2004) - hoitakse muust lahus ilukirjanduse lugemine. Kunstitekst kui esteetiliselt orienteeritud tekst on tervikmetafoor, mida ei saa analüüsida teabeteksti vahenditega ega memoreerida infokogumise võtetega. Teda ei saa taandada sõnale (Undusk 1992, 1998) ehk öelda, millest teos räägib või mis eesmärgil autor teose lõi. Paraku on Euroopas tavaline, et tuhanded lapsed koormavad oma mälu ilukirjandusteksti detailidega, teades et just neid õpetaja küsib. Küllaltki edumeelne on ka meie meediaõpetus. Näiteks on meediatekstide kriitilises võtmes analüüsi eesti kooli jaoks taganud Katrin Aava õpikomplekt (2003).

Üha enam tähtsustub aga keeleõppe tervik. Eluline on vajadus võõrkeeltes kogutud infot ja õppides leitut emakeeles täpselt edasi anda (vt Kerge 1998). Viimane eeldab muu hulgas teadmisi tõlkimisest (vt nt Tavast WWW). Nii ema- kui ka võõrkeeleõppes vajavad teadvustamist kultuurikontaktid ja teadmised kultuurierinevuste kohta (vt Pajupuu 2001). Ei oleks paha mõelda mõne kooli õppekavas mitmekeelse kommunikatsiooni ainele ja seada see ajapikku riiklike õppekavade läbivaks teemaks, hakates õpetajaid selleks aegsasti ette valmistama.

Kahjuks selgub asjaliku ja täpse keelekasutuse tähtsus inimesele alles siis, kui ta läheb edasi õppima ja tööle, seda olukorda ei ole aga võimalik muuta. Kui tunnistame, et keele omandamine on muu kogemusega seotud, siis ei ole ei gümnaasiumis ega ülikooliski võimalik inimest tööks ette valmistada, v.a otsene praktika. ${ }^{26}$ Seepärast peaks keeleaineid kavandades ette nägema, et tulevikus sõltub õpiedu muu seas kõrvaga kuulatud loengust, mida kiiresti mööduvana on raske tabada, ning tööedu kolleegi möödaminnes poetatud palvest, mis tuleb täpselt täita.

Selle kõrval ei saa läbi oskuseta end sõnaliselt selgeks teha, unustamata argumendina kasutada seda, mis autoriteetsetest tekstidest leida. Tekstide usaldusväärsuse üks mõõte on haritud keelekasutus, kuid ka seda ei saa tagada emakeeleõpetaja. Haritud inimeseks ei tee tema. Keeletundi jäävad väljendusoskuse suunamine ja stiililihv, ehkki stiilgi tuleb suuresti elu jooksul muutuvatest žanrieeskujudest ja inimese andest. Nii on täiskasvanute (ema)keeleõpe asutuste spetsiifikat arvestava sisekoolituse vormis väga nõutud.

Kui nüüd sellel taustal tulla tagasi eesti keele üldise oskuse kui ühiskonna eesmärgi juurde, siis saab selgeks, et ainult eestikeelne ja väga tugeva inglise keelega gümnaasium ja kõrgharidus ehk lõimitud aine- ja keeleõpe ${ }^{27}$ tagabki globaliseeruvas eestikeelses ühiskonnas toimetuleku. Vähem tähtis on, missugust tüüpi eesti keele eksami inimene sooritab. Tähtsam on, et ta suudaks emakeeles mõelda ja teises keeles väljenduda ning teiskeelset sõnumit emakeeles vahendada. Kogu mitmekeelse Euroopa ideoloogia ja kooliharidus on seega surnud punktis.

Keeleõpet ei saa aga kunagi üle tähtsustada. Inimene õpib paratamatult surmani, kellega, mida ja kuidas rääkida, ilma et ta seda teistega oma kultuuriruumiski ühtviisi tajuks (vt mitmeid artikleid lingvistilise antropoloogia kogumikust: Jourdan, Tuite 2006).

26 Nii on utoopiline ideaal, et vene- või saksakeelne gümnasist sooritaks eesti keele eksami maksimaalsel ehk C-tasemel. See ei ole gümnasistile emakeeleski saavutatav tase, sest muu kõrval mõõdetakse toimetulekut kõrgharidust nõudvates ametites (vt nt Eesti keeleseadust Riigi Teatajas).

27 Selle õppeviisi kohta saab teavet otsingutega LAK (ee) ja CLIL (content and language integrated learning). 


\section{Kokkuvõtteks}

Ei usu, et ülal esitatud arutlust oleks võimalik kokku võtta, pigem loodab see raamistada mõnd liiki tegevusi ja pakkuda mõtteainet. Ise pean kõige arendamisväärsemaks loo seda osa, mis üritab (mitte päris süsteemifunktsionaalselt, vaid väheke isemoodi) vaadata keelesüsteemi ja vajab viidetega-näidetega lahtikirjutamist. Ülejäänu väärib pigem propagandat ehk keelekihutust.

Tulen aga tagasi oma teksti alguses esitatud küsimuse juurde, kas lingvistika üldse enam rakenduse-täiendit vajabki.

Arvan omapäi, et täiendit on vaja ja et rakenduslingvistika erialasid on vaja lausa ühekaupa ülikoolis õpetada. ${ }^{28}$ Kindlasti vajavad oma eriala tõlkijad ja keeleõpetajad, kuid ehk on aeg mõelda sellistelegi inimestele, kes eesti keelt pidevalt suudaksid suhestada inglise keelega, näha läbi ja ennetada tegeliku kaks- või mitmekeelsuse karisid. Viimasel mõttel on taas mitu tah$\mathrm{ku}$ - tõlkida oskav emakeele- ja eesti keele õpetaja, hea eesti keelega inglise keele õpetaja ning keeli suhestav ametlik keelenõuanne. Samal ajal on eriti oluline, et kõigi ainete õpetajad saaksid piisava ettevalmistuse verbaalse kommunikatsiooni valdkonnas ning suudaksid kirjaoskuse arengut oma tundides toetada. Kas peaks avama näiteks leksikograafia magistrikava, ma ei tea, kuid rakenduslingvistika magistrikava leksikograafiale spetsialiseerumise mooduliga, seda küll. Ühisosa peaks rakenduslingvistika erialadel olema igal juhul; seda hariduse ühisosa vajavad kaudsed eesti keele erialadki (õigus, kommunikatsioon, meditsiin, pedagoogika).

Kogu eelnevast jutust kumab loodetavasti läbi ka see, et rakenduslingvistika on midagi niisama pealiskaudset kui ajakirjandus, kus sa tead kõike ja mitte midagi. Samal ajal lubavad vajalikud ja miks mitte aastati vahelduvad moodulid ning täiesti käepärased praktikakohad huvilisel kindlasti olla Jack of all trades ... and the master of your own. ${ }^{29}$ Eks see rakenduslingvistika mõlemat natuke eeldagi.

Sõna on meie eriala, ja ilma sõnata ju mõtteid ei vaheta, olgu neil siis teaduse või kunsti vorm.

Artikkel raamistab teoreetiliselt ETF-i grandiprojekti 8605 „Kirjutamise loomulikkuse mudel ja hindamine”.

28 Äkki suisa rakenduslingvistika bakalaureusekavaga alustades?

29 Viitan inglise ütlusele Jack of all trades but master of none, mille avapoolega sõnaliselt haakub 'iga asja peale meister', kuid mis tähendab pigem 'üheksa ametit ja kümnes nälg'. Olen muuseas üles kirjutanud artikli teemaga sobiva keelte kontaminatsiooni leiu, kus iga asja peale meister tähendas 20-aastase kasutaja jaoks halvustust - ilmselt oli ta sõnalähedasest tõlkest hoolimata üle kandnud inglise konnotatsiooni. Niisiis tabas noor inglise väljendi tooni, kuid mitte valitud emakeelevaste oma. Ise kohtasin sama inglaste ütlust esmakordselt just poolikuna ja pidasin kiituseks. 


\section{Kirjandus}

A a v a, Katrin, 2003. Veenmiskunst. Õpik gümnaasiumile. Töövihik; Veenmiskunst. Kõnekunst. Õpetajaraamat. Tallinn: Avita.

A a va, Katrin 2011. Teadmuspõhise ühiskonna ja elukestva õppe diskursuste rekontekstualiseerimine Eestis. - H. Metslang, M. Langemets, M.-M. Sepper (toim), Eesti Rakenduslingvistika Ühingu aastaraamat 7. Tallinn: ERÜ, lk 518.

B e a u g r a n d e, Robert-Alain de, D r e s s l e r, Wolfgang U. 1981. Introduction to Text Linguistics. London: Longman. Digitized version 2002: http://beaugrande. com/introduction_to_text_linguistics.htm (12. III 2012).

B e n k e, Gertraud 2003. Applied linguistics - a science of culture? - A. Hornscheidt (toim), Kulturanalyse in der Linguistik - Ist Linguistik eine Kulturwissenschaft? Linguistik online, $\mathrm{kd} 14, \mathrm{nr} 2$, lk 39-56. http://www.linguistikonline.de/ (20. IV 2012).

B e r g e r, Charles E. 1998. Message plans, communication failure, mutual adaption. - M. T. Palmer, G. A. Barnett (toim), Mutual Influence in Interpersonal Communication. (Progress in Communication Sciences XIV.) Stamford-London: Greenwood, lk 91-112.

B i b e r, Douglas 1995. Dimensions of Register Variation: A cross-linguistic comparison. Cambridge, New York: Cambridge University Press.

B o k h o r s t W e n g, Wendy 1999. Singapore's Speak Mandarin Campaign. Language ideological debates in the imagining of the nation. - J. Blommaert (toim), Language Ideological Debates. Berlin: Mouton de Gruyter, lk 235-266.

Brumfit, Christopher 1997. How applied linguistics is the same as any other science. - International Journal of Applied Linguistics, kd 7, nr 1, lk 86-94.

C o ble y, Paul (toim) 1996. The Communication Theory Reader. London-New York: Routledge.

D i j k, Teun van 2005. Ideoloogia. Tartu: Tartu Ülikooli kirjastus.

E h a l a, Martin, Ke r ge, Krista, L e paj õ e, Kersti, Sõ r m u s, Kadri 2010. Kõrgkoolide üliõpilaste eesti keele oskuse tase. Uuringukokkuvõte. Tartu: TÜ.

F r a th, Pierre 2009. Mitmekeelsuse paradoks Euroopas. - Sirp. Keele Infoleht, 13. III.

Gr e e n e, John O., B u r l e s o n, Brant R. 2003. Handbook of Communication and Social Interaction Skills. Mahwah: Lawrence Erlbaum.

H a cker, Douglas J., D un lo sk y, John, Graes s e r, Arthur C. (toim) 2009. Handbook of Metacognition in Education. Mahwah: Lawrence Erlbaum.

HAL = Karlfried Knapp, Gerd Antos (toim), Handbooks of Applied Linguistics. Communication Competence. Language and Communication Problems. Practical Solutions, kd. 1-9. Berlin-New York; Mouton de Gruyter, 2008-2009.

$\mathrm{H}$ a $\mathrm{l} \mathrm{l}$ i d a y, Michael A. K., W e b s t e r, Jonathan J. 2009. Continuum Companion to Systemic-Functional Linguistics. London-New York: Continuum Companions.

H a s a n, Reqaiya 2009. The place on context in systemic-functional model. M. A. K. Halliday, J. J. Webster, Continuum Companion to Systemic-Functional Linguistics. London-New York: Continuum Companions, lk 166-189.

H o ly o a k, Keith J., M or r i s o n, Robert G. (toim) 2005. The Cambridge Handbook of Thinking and Reasoning. New York: Cambridge University Press.

H o m a n n, Karl, S u c h a n e k, Andreas 2009. Sissejuhatus majandusteadusesse II. Tartu: TÜ majandusteaduskond, rahvamajanduse instituut. 
J a n i cki, Karol 2010. Confusing Discourse. Houndmills-New York: Palgrave MacMillan.

Janicki, Karol 2011. Communication and understanding. - A. Wilton, M. Stegu (toim), Applied Folk Linguistics. AILA Review, nr 24. Amsterdam-Philadelphia: John Benjamins, lk 68-77.

J o u r d a n, Christine, Tu i te, Kevin 2006. Language, Culture, and Society: Key topics in linguistic anthropology. Cambridge, New York-Melbourne-MadridCape Town-Singapore-São Paulo: CUP.

K a s i k, Reet 2002. Lingvistiline tekstianalüüs. - R. Pajusalu, I. Tragel, T. Hennoste, H. Õim (toim), Teoreetiline keeleteadus Eestis. (TÜ üldkeeleteaduse õppetooli toimetised 4.) Tartu: Tartu Ülikooli kirjastus, lk 74-88.

K a sik, Reet 2007. Võimu keel: asutus suhtleb kodanikuga. - Eesti Rakenduslingvistika Ühingu aastaraamat, nr 3, lk 167-176.

K e c s k e s, Istvan, 2008. Dueling contexts: A dynamic model of meaning. - Journal of Pragmatics, kd 40, lk 385-406.

K e r g e, Krista 1994. Keeletöö tänane ja tulevik (I): kes ja kuidas. Keeletöö tänane ja tulevik (II): mis ja miks. - Keel ja Kirjandus, nr 3, lk 145-149; nr 4, lk 196-202; nr 5, lk 285-290.

K e r g e, Krista 1998. Nüüdistekstid: kas suunamatu keelemuutus? - Keel ja Kirjandus, nr 4, lk 225-235.

K e r g e, Krista 2006. Ametlik viisakus ja kultuur. - Õiguskeel, nr 2, lk 3-8.

K e r g e, Krista 2008. Vilunud keelekasutaja. C1-taseme eesti keele oskus. Tallinn: Eesti Keele Sihtasutus.

K e r g e, Krista 2010. Muutustest õigusdiskursuses ja keeles. - Õiguskeel, nr 1, lk 146-152.

Ke r g e, Krista, M e i e r, Heidi 2010. Eesti õpilaste kirjaoskus. 2008/2009. õa emakeeleolümpiaadi tulemuste analüüs. Tallinn: TLÜ.

$\mathrm{K} n$ a p p, Karlfried, A n t o s, Gerd 2008. Introduction to the handbook series. Linguistics for problem solving. - K. Knapp, G. Antos (toim), Handbooks of Applied Linguistics. Communication Competence. Language and Communication Problems. Practical Solutions (HAL). ${ }^{30}$ Berlin-New York: Mouton de Gruyter, lk vii-xvii.

Kr e s s, Gunther 2000. A curriculum for the future. - Cambridge Journal of Education, kd 30, nr 1, lk 133-145.

Kre s s, Gunther 2007. Multimodality: a Social Semiotic Approach to Contemporary Communication. London, New York: Routledge.

Kre s s, Gunther, va n L e e u w e n, Theo 2004. Reading Images: the Grammar of Visual Design. London-New York: Routledge.

L a k o ff, Georg, J o h n s o n, Mark 2011. Metafoorid, mille järgi me elame. Tallinn: TLÜ kirjastus.

L a n g a cker, Ronald W. 2000. A dynamic usage-based model. - M. Barlow, S. Kemmer (toim), Usage-Based Models of Language. Stanford-California: CSLI Publications, lk 1-63.

L a n g e m e t s, Margit 2010. Nimisõna süstemaatiline polüseemia eesti keeles ja selle esitus eesti keelevaras. Tallinn: Eesti Keele Sihtasutus.

L e e uw en, Theo van 2005. Introducing Social Semiotics. London-New York: Routledge.

Littlej o hn, Stephen W., Foss, Karen A. 2009. Encyclopedia of Communication Theory. Kd 1. Thousand Oaks-London: Sage.

$30 \mathrm{Vt}$ allmärkust 2. 
L o t m a n, Juri 1992. Semiosfäärist. - Akadeemia, nr 10, lk 2019-2042.

M a c Ew a n, Arthur 1999. Neo-Liberalism or Democracy? Economic strategy, markets, and alternatives for the 21st century. London-New York: Zed Books.

N o o tr e, Sirje 2004. Kirjanduse kõnetus. Õpik gümnaasiumile. Töövihik, 1. osa; 2. osa. Ôpetajaraamat. Tallinn: Avita.

P a j u p u u, Hille 2001. Kuidas kohaneda võõras kultuuris. Tallinn: Eesti Keele Sihtasutus.

P a j u p u u, Hille, Ke r ge, Krista, M e i s te r, Lya, A s u, Eva Liina, A lp, Pilvi 2010. Natural speaking and how to assess it. - Trames: Journal of the Humanities and Social Sciences, kd 59, nr 2, lk 120-140.

P a l m e r, Mark T. 1998. Introduction. - M. T. Palmer, G. A. Barnett (toim), Mutual Influence in Interpersonal Communication. (Progress in Communication Sciences XIV.) Stamford, London: Greenwood, lk ix-xii.

Pavitt, Charles 2001. The Philosophy of Science and Communication Theory. Nova Science Publishers.

P u k s a n d, Helin, K e r g e, Krista 2012. Õpiteksti analüüs kirjaoskuse omandamise kontekstis. - Emakeele Seltsi aastaraamat, nr 57 (2011). Tallinn, lk 162217.

R a n n u t, Mart, R a n n u t, Ülle, Ve r s c h i k, Anna 2003. Keel. Võim. Ühiskond. Tallinn: TPÜ kirjastus.

S a h k a i, Heete 2011. Teine grammatika. Eesti keele teonimede süntaks konstruktsioonipõhises perspektiivis. (TLÜ humanitaarteaduse dissertatsioonid 25.) Tallinn: TLÜ.

T a m m e m ä g i, Anni, E h a l a, Martin 2012. Koolinoorte keelehoiakud 2011. aastal. - Keel ja Kirjandus, nr 4, lk 241-260.

Ta n n e n, Deborah 1991. You Just Don't Understand: Women and Men in Conversation. New York: Ballantine Books.

Ta v a s t, Arvi WWW. Mõiste mõiste: tähendusteooriate mõju oskuskeelepraktikale. http://enos.itcollege.ee/ ajarve/t\%E4hendusteooriate\%20m\%F5ju\%20oskuskeelepraktikale.pdf.

T a y 1 o r, Lynda 2006. The changing landscape of English: implications for language assessment. - ELT Journal, kd 60, nr 1, lk 51-60.

Tr a g e 1, Ilona 2003. Eesti keele tuumverbid. Tartu: Tartu Ülikooli kirjastus.

Trenholm, Sarah 1991. Human Communication Theory. Englewood Cliffs: Prentice Hall.

Un d u s k, Jaan 1992. Etüüdid tekstist. - Akadeemia, nr 5, lk 974-1013.

Un d u s k, Jaan 1998. Maagiline müstiline keel. Tallinn: Virgela.

Wodak, Ruth, Krzyżanowski, Michal (toim) 2008. Qualitative Discourse Analysis in Social Sciences. Houndmills, New York: Palgrave MacMillan.

Õ i m, Haldur 1996. Teoreetiline keeleteadus ja integreeritud keeleteooria. - Keel ja Kirjandus, nr 11, lk 731-744.

Õ i m, Haldur 2001a. Eesti keeleteadusliku mõtte areng XX sajandil. - Keel ja Kirjandus, nr 7, lk 468-479.

Õ i m, Haldur 2001b. Keeletehnoloogiast ja eesti keelest. - Keel ja Kirjandus, nr 7, lk 499-501.

Õ i m, Haldur 2008. Kognitiivne pööre. - Keel ja Kirjandus, nr 8-9, lk 617-627.

Õ i m, Haldur, Tr a g e l, Ilona 2007. Teoreetilise keeleteaduse arengust mujal ja meil XXI sajandi alguses. - Keel ja Kirjandus, nr 2, lk 98-115. 


\section{Räägiks lingvistikast}

Keywords: Estonian, applied linguistics, developments in linguistics, language and society

It is discussed how knowledge about language and its functioning is or could be applied to fields where language professionals are active (teaching languages and cultures, translation, lexicography, editing and other communication advisory, media-analysis, terminology, language technology, etc.). All these professionals work for others to succeed in verbal communication.

On the background, the effects of globalization and formation of cross-cultural identity groups within society are discussed. In all these new groups beyond a traditional opaque language society, English is used as a lingua franca. According to Lotman's (1984) theory, semiosis and development of human cognition, knowledge, and cultural values never take place in the centre of a semiosphere but only in the common periphery of at least two of them. In this process, a new centre of the two is developed. This means that in the future, a very small language community (such as Estonian) cannot really expect to retain a common cultural centre and common polyfunctional language to keep the community and its education up to date. On the other hand, similar processes are taking place all over Europe, incl. among scientists strongly feeling the pressure of having to be both international and of a school (the SIG-effect). By the advancement of multiand plurilinguality, there are also signals to be worried about individuals and thus for the stable future of European society.

Krista Kerge (b. 1952), PhD, Tallinn University, Institute of Estonian Language and Culture, professor of applied linguistics, krista.kerge@tlu.ee 